\title{
The environmental Kuznets curve in the case of Russia
}

\author{
Natalya Ketenci* \\ Yeditepe University, Istanbul, Turkey
}

\begin{abstract}
This study explores the relationships between carbon emissions and their main determinants such as energy consumption, real income, international trade, level of education and level of urbanization in the Russian Federation, employing data for the period 1991-2016. Support for the environmental Kuznets curve hypothesis is found in this study, stating that environment pollution decreases in Russia after income achieves a certain threshold. The ARDL bounds test is employed in order to estimate short-run and long-run relationships in the estimated model. Energy consumption, real income, education and urbanization levels are found to be significant determinants of carbon emissions, while trade openness does not have an impact. The Granger causality test indicates two-way relationships between carbon emissions and energy use, real income and education. Only a single oneway causality runs from carbon emission to trade and no causality was found between carbon emissions and level of urbanization.
\end{abstract}

Keywords: $\mathrm{CO} 2$ emissions, environment Kuznets curve, cointegration, Russia. JEL classification: Q51.

\section{Introduction}

Russia is one of the largest contributors in the world to carbon dioxide $\left(\mathrm{CO}_{2}\right)$ emissions after China, the US and India in total kilotons (kt). However, in terms of kilogram (kg) of $\mathrm{CO}_{2}$ emissions per 2010 dollars of GDP in 2014, Russia left the US far behind with $0.99 \mathrm{~kg}$ compared to $0.33 \mathrm{~kg}$ in the US. Contrary to the general tendency of decline in $\mathrm{CO}_{2}$ emissions among developed countries, $\mathrm{CO}_{2}$ emissions in Russia continue to rise. Since 1998, Russia has increased $\mathrm{CO}_{2}$ emissions by 14 percent, making an 8 percent overall increase since 2009. The changes are in favor of the environment, however, if GDP is taken into account as $\mathrm{CO}_{2}$ emissions per 2010 dollars of GDP declined by 45.6 percent in 2014

\footnotetext{
* E-mail address: nketenci@yeditepe.edu.tr
} 
from 1998 levels and by 7.3 percent from 2009. ${ }^{1}$ This is explained by the use of more environmentally-friendly equipment in the growing economy.

In 2015, the Russian Federation declared, as its target of intended nationally determined contribution (INDC), a decrease in the level of greenhouse gas (GHG) emissions by 25-30 percent from the 1990 level by 2030. However, this target is criticized in literature on the grounds that, in 2012, emissions in Russia were already 68 percent of the 1990 level (Korppoo and Kokorin, 2017). Even though Russia has reached its target and is working to maintain it for the next decade, it continues to be one of the largest contributors to $\mathrm{CO}_{2}$ emissions in the world.

New policies need to be designed in order to follow the global continuous declining trend. For example, since 1990, the environmental policy of the European Union (EU) has been focused on the commitment of its countries to decrease greenhouse emissions by 40 percent by 2030. In 2015, 195 countries signed the Paris Agreement, one of the important goals of which is to decrease world greenhouse emissions.

This study investigates factors affecting $\mathrm{CO}_{2}$ emissions in Russia that contribute to climate policies. At the same time, it examines the environmental Kuznets curve hypothesis in the context of that country. Factors of $\mathrm{CO}_{2}$ emissions in Russia have not been investigated empirically to date using an expanded framework. Therefore, the aim of this study is to conduct the first test of the environmental Kuznets curve in Russia by eliminating omitted variables bias, investigating the long-run relationships between $\mathrm{CO}_{2}$ emissions and variables that are responsible for changes, such as energy use, income per capita, trade openness, education and degree of urbanization. The next part reviews empirical findings in literature. The third part introduces the methodology applied in this paper and then empirical results are outlined in the fourth part, followed by a discussion in the conclusion on policy implications.

\section{Literature review}

The problem of worsening environmental quality has been receiving increased attention in literature. Most of the empirical studies have been conducted within the framework of the environmental Kuznets curve (EKC). The EKC hypothesis assumes an inverted U-curve relationship between environmental degradation and income per capita. With an increase in income, pollution initially rises as well; however, after the economic growth reaches a certain threshold, levels of pollution start to decrease. Testing the EKC hypothesis, some studies explain changes in environmental quality purely by economic growth (Panayotou 1993; Grossman and Krueger, 1995; Ekins, 1997; Stern 2004; Narayan and Narayan, 2010). However, recently more studies have begun to identify additional factors that may play important roles in environmental degradation processes. For example, energy consumption is considered a key determinant of environmental quality (Ang, 2007; Acaravci and Özturk, 2010; Pao et al., 2011; Saboori and Sulaiman 2013; Shahbaz et al., 2013; Baek, 2015). Numerous studies agree that energy consumption is mostly responsible for $\mathrm{CO}_{2}$ emissions (Pablo-Romero and

1 World Development Indicators Database. 
Jesus, 2016) and directly or indirectly plays the principal role in environmental problems (Suri and Chapman, 1998).

However, recently more studies have incorporated the factor of international trade (Suri and Chapman, 1998; Cole, 2004; Halicioğlu, 2009; Jayanthakumaran and Liu 2012; Saboori et al., 2012; Lau et al., 2014; Jebli et al., 2016). The liberalization of international trade has encouraged greater production, leading to economic growth, which in turn has created solutions to environmental degradation (Arrow et al., 1996). International trade leads to the movement of products produced in one country to other countries where they are consumed or involved in further production. Therefore, with the increase in trade, pollutant emissions may move to other countries (Halicioğlu, 2009). Suri and Chapman (1998) found that the export of manufactured goods in industrializing countries is the main determinant of increased energy consumption leading to the rapid growth of pollution, while imports of manufactured goods in industrialized countries are partly responsible for a decline in pollutant emissions.

In order to solve the problem of omitted variables, in literature, different determinants are incorporated in the EKC framework. For example, urbanization has been found to have a dual effect on the environment (Managi and Jena, 2008; Wang et al. 2008; Kasman and Duman, 2015). Generally, it is believed that higher levels of urbanization lead to higher levels of pollution due to greater population. However, improved levels of disposal organization and hygiene provisions in urban areas may create positive relationships between urbanization and environmental quality (Gangadharan and Valenzuela, 2001). The effect of education on environmental quality may vary as well (Hill and Magnani, 2002; Farhani et al., 2014). As discussed in Balaguer and Cantavella (2018), with an increase in the level of education, more knowledge is extracted for the consumption of technology-intensive products, which are relatively more polluting products. However, education can lead to social awareness and motivate people to improve environmental quality by decreasing their consumption of non-renewable products and by improving disposal separation.

Some researchers argue that energy prices play an important role in the EKC (Agras and Chapman, 1999; Lindmark, 2002; Richmond and Kaufmann, 2006; He and Richard, 2010; Al-Mulali and Özturk, 2016; Katircioğlu, 2017). Energy prices are considered a key determinant of pollution although the effect may be negative as well as positive. Higher energy prices encourage producers to substitute energy-intensive technologies for less intensive ones, which leads to a decline in pollution. On the other hand, higher energy prices stimulate higher production of energy, leading to increased levels of pollution (He and Richard, 2010).

To eliminate the possibility of omitted variable bias, researchers include in the EKC framework analysis such variables as inequality (Torras and Boyce, 1998; Magnani, 2000; Heerink et al., 2001), tourism (Katircioğlu, 2014; Arbulu et al., 2015; Zaman et al., 2016), financial development (Tamazian et al., 2009; Jalil and Feridun, 2011; Katircioğlu and Taspinar, 2017) and health (Gangadharan and Valenzuela, 2001; Brajer et al., 2008; and Khan et al., 2016).

The list of major contributors to world $\mathrm{CO}_{2}$ emissions consists of developed as well as developing countries; therefore, numerous studies on the EKC hypothesis 
include developed (Millimet et al., 2006; Iwata et al., 2010; Esteve and Tamarit, 2012; Shahbaz et al., 2015; Pablo-Romero et al., 2017) as well as developing and transition countries (Bulte and Soest, 2001; Fodha and Zaghdoud, 2010; Al-Mulali et al., 2015; Jebli and Youssef, 2015; Özturk and Al-Mulali, 2015; Li et al., 2016). While there is no common conclusion for developed countries within the EKC framework, numerous studies on developing countries reveal that there is no "one-fit-for-all" relationship between economic growth and environmental quality, where developing countries do not wait for an increase in income to reach the threshold for environmental improvement, but design their own environment improvement path (He, 2016).

In support of general findings, Halicioğlu and Ketenci (2016) revealed support for the existence of EKC only in three out of fifteen transition countries. Sirag et al. (2017) estimated that the income level in developing countries is below the desired threshold for environmental improvements where the government environmental policies suggested the EKC would be inappropriate. Sayed and Sek (2013) tested the EKC hypothesis in developed and developing countries by decomposing emissions by various environmental measures. Their results, in contrast to previous studies, support the existence of the EKC in most cases of developed and developing countries; however, the income threshold in developed countries is higher than that in developing ones. Alternative methodologies may vary the outcome, thus Stern (2004) criticizes previously employed methodologies of total pollution analysis that may lead to ambiguous results. The author suggests that various decompositions of emissions in analysis may help to enlighten relationships between emissions and economic growth.

Despite the interest in literature in the EKC for polluting countries, empirical studies for Russia are few in number. Among them are Pao et al. (2011), who found in their dynamic study that emissions are "output inelastic" and the EKC is not supported. Halicioğlu and Ketenci (2016) and Yang et al. (2017) found support for the EKC in Russia, where the economy-related greenhouse emissions are presented by energy consumption, emissions from industrial process, from animal husbandry and fugitive emissions. The validity of the environmental Kuznets curve for Russian regions has been tested with mixed results by Mihalischev and Raskina (2015), Rudenko and Skripnuk (2016) and for cities by Ivanova and Vertkina (2017). The results on the EKC existence are controversial as well as in studies where Russia is included in the panel of BRIC countries. For example, Pao and Tsai (2011) found the results in support of the EKC, while the results of estimations in Chang (2015) illustrate that the EKC in BRICS countries is U-shaped, which is opposite to conventional findings.

There is no common conclusion in literature on the long-run relationships between $\mathrm{CO}_{2}$ emissions and income. There is also no expanded research on EKC for Russia. This study thus seeks to fill the gap in literature.

\section{Econometric methodology}

Taking into account the mixed results in literature on the environmental Kuznets curve to eliminate omitted variables bias, the relationships between $\mathrm{CO}_{2}$ emissions and economic growth following similar methodologies in previous studies of Hossain (2011), Ferhani et al. (2014), Kasman and Duman (2015) 
and Balaguer and Cantavella (2018) is expressed in the following three alternative equations:

$$
\begin{aligned}
& c_{t}=\beta_{0}+\beta_{1} e_{t}+\beta_{2} y_{t}+\beta_{3} y_{t}^{2}+\beta_{4} t r_{t}+\beta_{5} e d_{t}+\varepsilon_{1 t} \\
& c_{t}=\beta_{0}+\beta_{1} e_{t}+\beta_{2} y_{t}+\beta_{3} y_{t}^{2}+\beta_{4} t r_{t}+\beta_{5} u_{t}+\varepsilon_{2 t} \\
& c_{t}=\beta_{0}+\beta_{1} e_{t}+\beta_{2} y_{t}+\beta_{3} y_{t}^{2}+\beta_{4} t r_{t}+\beta_{5} e d_{t}+\beta_{6} u_{t}+\varepsilon_{3 t}
\end{aligned}
$$

where $c_{t}$ is $\mathrm{CO}_{2}$ emissions per capita; $e_{t}$ is commercial energy use per capita; $y_{t}$ represents per capita real income, which is measured as GDP per capita; $y_{t}^{2}$ is the square of per capita income; $t r_{t}$ is trade openness and measured in terms of sum of export and import as a share of GDP; $e d_{t}$ is the level of education measured in the number of secondary education pupils; and $u_{t}$ is the urban population as a share of total population.

The reason behind employing three alternative models, where education and urbanization are altered as explanation variables, is the robustness check to eliminate the omitted variables bias. It is discussed in literature that energy consumption is the key determinant in emissions changes; therefore, it is expected that $\beta_{1}$ has a positive sign (Suri and Chapman, 1998). The EKC hypothesis assumes that $\beta_{2}$ is positive and $\beta_{3}$ is negative, demonstrating an increase in emission with economic growth and further improvement in environmental quality after income reaches a certain threshold. Coefficients of trade openness, $\beta_{4}$, may be positive as well as negative. With an increase in the reallocation of the international trade production of some products between countries, pollution related to production is being reallocated as well (Halicioğlu, 2009). The coefficients of education and urbanization variables may have either positive or negative signs. Increased levels of urbanization and education provide better access to advanced technologies consumption, which is usually energy-intensive and leads to higher levels of pollution. However, improved levels of disposal organization and of hygiene provision may decrease emissions in urban areas (Gangadharan and Valenzuela, 2001). Increased educational levels expand social awareness of environmental problems and can lead to improvements in environmental quality (Balaguer and Cantavella, 2018).

\subsection{Unit root analysis}

The methodology employed in this study allows for $\mathrm{I}(0), \mathrm{I}(1)$ or fractionally integrated variables; however, it is not designed for I(2) integrated variables. Therefore, in order to check that variables are not integrated of order 2 , four alternative unit root tests were conducted. These are the Dickey and Fuller (1979) Augmented Dickey Fuller (ADF) test, the Dickey-Fuller generalized least squares (DF-GLS) test proposed by Elliot et al. (1996), the Phillips and Perron (1988) PP test and the KPSS (Kwiatkowski et al., 1992) test. The null hypothesis of the ADF, DF-GLS and PP tests is the unit root presence versus the alternative hypothesis that series are generated by a stationary process. The KPSS test is an alternative test to conventional tests and offers the null hypothesis of stationarity versus the alternative hypothesis of non-stationarity. 


\subsection{ARDL co-integration analysis}

Due to the relatively low span of data, the Pesaran et al. (2001) bounds testing approach is employed in this study. This approach is also known as the autoregressive distributed lag model (ARDL) and is superior to the Johansen cointegration test due to its numerous advantages (Pesaran and Shin, 1999). One of the key advantages is that the ARDL approach can be applied irrespective of the integration order of variables $\mathrm{I}(0), \mathrm{I}(1)$ or a combination of both; however the test is not valid in the presence of $\mathrm{I}(2)$ variables. The problem of endogeneity is avoided in the ARDL approach as it corrects for residual serial correlation. Another advantage is that the approach allows for different lags of variables in the data generating process. On the other hand, the ARDL process estimates short run parameters through the error correction model (ECM) adjustments. The ARDL procedure starts with the investigation of the co-integration existence amongst estimated variables. The first stage of the bounds test examines long run relationships, where the ARDL framework of the Model 1 can be expressed as follows ${ }^{2}$ :

$$
\begin{aligned}
\Delta c_{t}=\alpha_{0} & +\sum_{i=1}^{p} \alpha_{1 i} \Delta c_{t-i}+\sum_{i=0}^{p} \alpha_{2 i} \Delta e_{t-i}+\sum_{i=0}^{p} \alpha_{3 i} \Delta y_{t-i}+\sum_{i=0}^{p} \alpha_{4 i} \Delta y_{t-i}^{2}+ \\
& +\sum_{i=0}^{p} \alpha_{5 i} \Delta t r_{t-i}+\sum_{i=0}^{p} \alpha_{6 i} \Delta e d_{t-i}+\alpha_{7} c_{t-i}+\alpha_{8} e_{t-1}+\alpha_{9} y_{t-1}+ \\
& +\alpha_{10} y_{t-1}^{2}+\alpha_{11} t r_{t-1}+\alpha_{12} e d_{t-1}+\mu_{t}
\end{aligned}
$$

where $\alpha_{1 i}, \alpha_{2 i}, \alpha_{3 i}, \alpha_{4 i}, \alpha_{5 i}, \alpha_{6 i}$ represent the short-run parameters of estimated variables and $\alpha_{7 i}, \alpha_{8 i}, \alpha_{9 i}, \alpha_{10 i}, \alpha_{11 i}, \alpha_{12 i}$ are the corresponding long-run parameters. The procedure is based on the joint $\mathrm{F}$ or Wald-statistics, where the null hypothesis of no co-integration in Eq. (4) is $\mathrm{H}_{0}: \alpha_{7}=\alpha_{8}=\alpha_{9}=\alpha_{10}=\alpha_{11}=\alpha_{12}=0$, against the alternative hypothesis $\mathrm{H}_{1}: \alpha_{7} \neq \alpha_{8} \neq \alpha_{9} \neq \alpha_{10} \neq \alpha_{11} \neq \alpha_{12} \neq 0$. Critical values for the bound test are reported in Pesaran and Pesaran (1997) and in Pesaran et al. (2001), where one set of values is computed assuming that variables are I(0) and another set is computed assuming that all variables are I(1). If the calculated F-statistics lie above the upper bound of the critical values, the null hypothesis of no co-integration is rejected. If the F-statistics lie below the lower critical bound, the null hypothesis cannot be rejected. In the case where the test statistics fall between lower and upper bounds of critical values, the test is inconclusive.

After the co-integration has been established, the ECM for Model 1 is estimated in the following form ${ }^{3}$ :

$$
\begin{aligned}
\Delta c_{t}=\delta_{0} & +\sum_{i=1}^{p} \delta_{1 i} \Delta c_{t-i}+\sum_{i=0}^{p} \delta_{2 i} \Delta e_{t-i}+\sum_{i=0}^{p} \delta_{3 i} \Delta y_{t-i}+\sum_{i=0}^{p} \delta_{4 i} \Delta y_{t-i}^{2}+ \\
& +\sum_{i=0}^{p} \delta_{5 i} \Delta t r_{t-i}+\sum_{i=0}^{p} \delta_{6 i} \Delta e d_{t-i}+\lambda_{1} E C_{t-1}+v_{t}
\end{aligned}
$$

\footnotetext{
2 The ARDL framework for Models 2 and 3 for the space consideration are presented in the Appendix.

3 The ECM framework for Models 2 and 3 for the space consideration are presented in the Appendix.
} 
where $E C_{t-1}$ is the error correction term and $\lambda_{1}$ is the parameter that measures the speed of variables convergence to the equilibrium, which has to be statistically significant with negative sign.

\section{Empirical results}

\subsection{Data}

This study employs annual data of carbon emissions and their main determinants such as energy consumption, real income, international trade, level of education and level of urbanization in the Russian Federation for the period 1991-2016. The data are collected from the World Bank's World Development Indicators database. Carbon emissions are presented by $\mathrm{CO}_{2}$ emissions per capita, metric tonnes; energy consumption is commercial energy use per capita, $\mathrm{kg}$ of oil equivalent; real income is represented by GDP per capita, constant 2010 US dollars; international trade is the sum of export and import as a share of GDP; level of education is the number of secondary education pupils; and level of urbanization is expressed by the urban population as a share of total population. All variables are used in natural logarithms.

Descriptive statistics of the sample are presented in Table 1. On average, carbon emissions in Russia consist of 11.59 metric tonnes per capita for the estimated period, while energy consumption is $4663.75 \mathrm{~kg}$ of oil equivalent per capita. Trade openness on average is 55.25 with the maximum value of 110.58 in 1992 with the following stabilization of trade openness to its average. The urbanization level is more stable compared to other variables and performs slow continuous growth.

\subsection{Unit root analysis}

This study employs annual data for the period 1991-2016 in order to investigate relationships between $\mathrm{CO}_{2}$ emissions and variables that may determine its changes, energy consumption, real income, international trade and levels of education and urbanization in the Russian Federation. The ARDL technique employed in this study allows for variables that are integrated of order 0 or $1, \mathrm{I}(0)$ or I(1); however, the procedure does not allow for integration of order above 1. Therefore, to examine the order of variables integration, four alternative unit root tests are employed in this study, the ADF, the DF-GLS, the PP and the KPSS.

Table 1

Descriptive statistics.

\begin{tabular}{lrrrrl}
\hline & \multicolumn{1}{c}{ Mean } & \multicolumn{1}{c}{ Max. } & \multicolumn{1}{c}{ Min. } & \multicolumn{1}{c}{ St. dev. } & Obs. \\
\hline$c$ & 11.59 & 14.00 & 10.13 & 1.02 & 26 \\
$e$ & 4663.75 & 5861.16 & 3981.51 & 441.89 & 26 \\
$y$ & 8637.84 & 11615.70 & 5505.63 & 2216.03 & 26 \\
$t r$ & 55.25 & 110.58 & 26.26 & 14.31 & 26 \\
$e d$ & 12558496 & 15862637 & 9061324 & 2636478 & 26 \\
$u$ & 73.54 & 74.10 & 73.34 & 0.26 & 26 \\
\hline
\end{tabular}

Notes: Max. is the abbreviation for maximum value of a variable, Min. is for the minimum value, St. dev. is referred to a standard deviation, Obs. is the number of observations. 
Table 2

Unit root tests.

\begin{tabular}{lllll}
\hline & ADF & DF-GLS & PP & KPSS \\
\hline$c$ & $-3.47^{* *}$ & $-3.55^{*}$ & $-3.47^{* *}$ & 0.29 \\
$e$ & $-3.48^{* *}$ & $-2.82^{*}$ & $-3.43^{* *}$ & 0.35 \\
$y$ & $-3.08^{* *}$ & $-2.14^{* *}$ & $-3.09^{* *}$ & 0.28 \\
$t r$ & $-4.22^{*}$ & $-3.07^{*}$ & $-14.31^{*}$ & 0.33 \\
$e d$ & $-4.83^{*}$ & $-3.02^{*}$ & -1.24 & 0.19 \\
$u$ & 0.63 & -0.07 & 0.62 & $0.68^{* *}$ \\
\hline
\end{tabular}

Notes: The null hypothesis of ADF, DF-GLS and PP unit root tests is the presence of the unit root. The null hypothesis of the KPSS test is the stationarity of an estimated variable. * and ** denote the rejection of the null hypothesis at the $1 \%$ and $5 \%$ significance levels, respectively.

The results of the unit root analysis are presented in Table 2. The results show that all variables, except the urbanization level, are generated by a stationary process where the urbanization level has a unit root. From the results of the unit root estimations, it is evident that all variables of estimation are integrated of the order 0 or 1 and none is integrated of the order above 1 .

\subsection{ARDL co-integration analysis}

After detecting the order of variables integration, the ARDL co-integration approach is employed. The first stage is the selection of the optimum lag length of the unrestricted vector auto regression (VAR). The Akaike Information Criterion (AIC) and the Schwarz Bayes Criterion (SBC) imply that the optimal lag length is 2 . The second stage of the analysis involves the investigation of log-run relationships between dependent and independent variables. A bound F-test is employed for equations (4), (6) and (7). The results of the test are reported in Table 3. Three different models are estimated, where an alternative combination of independent variables is used. Unchanged dependent variables in three alternative models are energy consumption, real income, square of the real income and international trade. The difference between models is that the first model includes education level, the second model includes urbanization level and the last model includes both education and urbanization levels. The results for all three models reveal that estimated F-statistics are above the upper bound level, indicating the existence of co-integration between variables in the three alternative models.

After the long-run relationships were detected, the short-run and long-run coefficients were estimated. The short-run results and diagnostic test statistics are presented in Table 4. The estimate of the error correction model (ECM) term is significant with an expected negative sign, which confirms the co-integration. The value of the ECM coefficient is about 0.95 for all models, which implies that about $95 \%$ of the $\mathrm{CO}_{2}$ emissions disequilibrium in the short run is rectified annually. The results of diagnostic statistics, presented in Table 3 and Table 4, indicate the good fit of models represented by $R^{2}$ and significant $\mathrm{F}$ statistics and that models are free of economic problems, specifically the Durbin-Watson statistics imply that error terms are not correlated, there is no autocorrelation in the disturbance of the error term as presented by the Breusch-Godfrey test and finally the models pass the normality test. As expected, energy consumption and 
Table 3

Cointegration $\mathrm{F}$ test, $\mathrm{F}\left(c \mid e, y, y^{2}, t, e d\right)$.

\begin{tabular}{lccllll}
\hline F-statistics & $95 \% \mathrm{LB}$ & $95 \% \mathrm{UB}$ & $90 \% \mathrm{LB}$ & $90 \% \mathrm{UB}$ & $99 \% \mathrm{LB}$ & $99 \% \mathrm{UB}$ \\
\hline $\begin{array}{l}\mathrm{F}\left(c \mid e, y, y^{2}, t, e d\right) \\
\mathbf{5 . 2 5}\end{array}$ & 2.39 & 3.38 & 2.08 & 3 & 3.06 & 4.15 \\
$\begin{array}{l}\mathrm{F}\left(c \mid e, y, y^{2}, t, u\right) \\
\mathbf{7 . 6 9}\end{array}$ & 2.39 & 3.38 & 2.08 & 3 & 3.06 & 4.15 \\
$\mathrm{~F}\left(c \mid e, y, y^{2}, t, e d, u\right)$ & & & & & \\
$\mathbf{5 . 0 8}$ & 2.27 & 3.28 & 1.99 & 2.94 & 2.88 & 3.99 \\
\hline
\end{tabular}

Notes: Null hypothesis of the bounds test is: No long-run relationship exists. LB — low bound, UB — upper bound. If the F test statistic falls between lower and upper bounds the result is inconclusive. If it is below lower bound, the null hypothesis cannot be rejected. If the test statistics is above upper bound, the null hypothesis of no co-integration is rejected.

Table 4

ARDL short run results.

\begin{tabular}{|c|c|c|c|c|c|c|c|c|}
\hline \multicolumn{3}{|c|}{$\overline{\mathrm{F}}\left(c \mid e, y, y^{2}, t, e d\right)$} & \multicolumn{3}{|c|}{$\mathrm{F}\left(c \mid e, y, y^{2}, t, u\right)$} & \multicolumn{3}{|c|}{$\mathrm{F}\left(c \mid e, y, y^{2}, t, e d, u\right)$} \\
\hline Regressors & $\beta$ & $t$-ratios & Regressors & $\beta$ & $t$-ratios & Regressors & $\beta$ & $t$-ratios \\
\hline$\Delta e$ & 1.19 & $26.57 *$ & $\Delta e$ & 1.06 & $22.63 *$ & $\Delta e$ & 1.17 & $24.99 *$ \\
\hline$\Delta y$ & 0.01 & $6.03 *$ & $\Delta y$ & 0.01 & $5.05 *$ & $\Delta y$ & 0.01 & $5.77 *$ \\
\hline$\Delta y^{2}$ & -0.27 & $-6.39 *$ & $\Delta y^{2}$ & -0.23 & $-5.45^{*}$ & $\Delta y^{2}$ & -0.27 & $-5.91 *$ \\
\hline$\Delta t r$ & -0.02 & -1.99 & $\Delta t r$ & 0.01 & 1.37 & $\Delta t r$ & -0.02 & -1.86 \\
\hline \multirow[t]{2}{*}{$\Delta e d$} & 0.09 & 1.12 & $\Delta u$ & -3.11 & -1.62 & $\Delta e d$ & 0.09 & 1.17 \\
\hline & & & & & & $\Delta u$ & -1.16 & -0.56 \\
\hline $\mathrm{ECM}_{t-1}$ & -0.96 & $-6.86^{*}$ & $\mathrm{ECM}_{t-1}$ & -0.98 & $-5.39 *$ & $\mathrm{ECM}_{t-1}$ & -0.95 & $-6.09 *$ \\
\hline \multicolumn{9}{|c|}{ Diagnostic test statistics } \\
\hline$R^{2}$ & 0.72 & & $R^{2}$ & 0.92 & & $R^{2}$ & 0.74 & \\
\hline DW-statistic & 2.13 & & DW-statistic & 2.43 & & DW-statistic & 2.28 & \\
\hline F-statistic & 4.72 & & F-statistic & 14.42 & & F-statistic & 4.63 & \\
\hline RSS & 0.01 & & RSS & 0.01 & & RSS & 0.01 & \\
\hline
\end{tabular}

Notes: $*$ and $* *$ denote the rejection of the null hypothesis at the $1 \%$ and $5 \%$ significance levels respectively. $\beta$ columns report estimated coefficients.

real income have a positive effect on $\mathrm{CO}_{2}$ emissions in the short run, while trade, education and urbanization levels are insignificant in all three models.

The long-run results of the ARDL estimations are presented in Table 5. Estimates of all variables except trade were found significant. Energy consumption and real income per capita were found to be positively related to $\mathrm{CO}_{2}$ emissions. The impact of energy consumption is stronger compared to income. An increase in energy consumption per capita by 1 percent leads to an increase in $\mathrm{CO}_{2}$ emissions per capita by more than 100 percent, while 1 percent increase in real income per capita causes a 1 percent increase in emissions. The hypothesis of the EKC is supported by estimates in all three models, where the positive sign of real income and the negative sign of real income squared, determine inverted U-shape relationships between $\mathrm{CO}_{2}$ and real income. These results are in line with the findings of Yang et al. (2017); however, the results of Pao et al. (2011) do not support the EKC hypothesis for Russia, which may be due to the lower span of data employed in the study or due to a bias of omitted variables.

The magnitude of the negative impact of real income squared is slightly higher when compared to the positive impact of real income on $\mathrm{CO}_{2}$ emis- 
Table 5

ARDL long run results ARDL (1,0,0,0,0,2).

\begin{tabular}{|c|c|c|c|c|c|c|c|c|}
\hline \multicolumn{3}{|c|}{$\begin{array}{l}\overline{\mathrm{F}\left(c \mid e, y, y^{2}, t, e d\right)-} \\
\mathrm{ARDL}(1,0,0,0,0,2)\end{array}$} & \multicolumn{3}{|c|}{$\begin{array}{l}\mathrm{F}\left(c \mid e, y, y^{2}, t, u\right)- \\
\operatorname{ARDL}(1,0,2,2,0,0)\end{array}$} & \multicolumn{3}{|c|}{$\begin{array}{l}\mathrm{F}\left(c \mid e, y, y^{2}, t, e d, u\right)- \\
\operatorname{ARDL}(1,0,0,0,0,2,0)\end{array}$} \\
\hline Regressors & $\beta$ & $t$-ratios & Regressors & $\beta$ & $t$-ratios & Regressors & $\beta$ & $t$-ratios \\
\hline$e$ & 1.27 & $39.09 *$ & $e$ & 1.14 & $23.64 *$ & $e$ & 1.26 & $32.08^{*}$ \\
\hline$y$ & 0.01 & $4.62 *$ & $y$ & 0.01 & 0.76 & $y$ & 0.01 & $4.13^{*}$ \\
\hline$y^{2}$ & -0.28 & $-5.97 *$ & $y^{2}$ & -0.08 & -1.49 & $y^{2}$ & -0.27 & $-4.79 *$ \\
\hline$t$ & -0.02 & -1.01 & $t$ & 0.02 & 0.97 & $t$ & -0.02 & -0.98 \\
\hline ed & 0.09 & $2.57 * *$ & $u$ & -3.27 & $-2.15^{* *}$ & ed & 0.09 & $2.23^{*}$ \\
\hline \multirow[t]{2}{*}{$c$} & -5.18 & $-6.34^{*}$ & $c$ & 8.08 & 1.14 & $u$ & -0.84 & -0.41 \\
\hline & & & & & & $c$ & -1.59 & -0.18 \\
\hline \multicolumn{9}{|c|}{ Diagnostic test statistics } \\
\hline & $t$-ratios & $p$-values & & $t$-ratios & $p$-values & & $t$-ratios & $p$-values \\
\hline$\chi_{S C}^{2}$ & 1.72 & 0.22 & & 2.11 & 0.16 & & 2.49 & 0.32 \\
\hline$\chi_{F F}^{2}$ & 0.09 & 0.92 & & 0.04 & 0.96 & & 0.24 & 0.81 \\
\hline$\chi_{N}^{2}$ & 3.78 & 0.15 & & 0.09 & 0.95 & & 3.56 & 0.16 \\
\hline$\chi_{H}^{2}$ & 0.84 & 0.59 & & 1.29 & 0.32 & & 0.80 & 0.62 \\
\hline
\end{tabular}

Notes: $*$ and $* *$ denote the rejection of the null hypothesis at the $1 \%$ and $5 \%$ significance levels respectively. $\beta$ columns report estimated coefficients. $\chi_{S C}^{2}, \chi_{F F}^{2}, \chi_{N}^{2}, \chi_{H}^{2}$ present the Breusch-Godfrey serial correlation LM test, the Ramsey RESET test of functional form misspecification, the Jarque-Bera normality test and the BreuschPagan-Godfrey heteroskedasticity test, respectively.

Table 6

Pairwise Granger causality test.

\begin{tabular}{ccl}
\hline Null Hypothesis & F-statistics & Probability \\
\hline$e$ does not Granger cause $c$ & 6.695 & 0.006 \\
$c$ does not Granger cause $e$ & 12.055 & 0.001 \\
$y$ does not Granger cause $c$ & 4.224 & 0.030 \\
$c$ does not Granger cause $y$ & 3.402 & 0.055 \\
$y^{2}$ does not Granger cause $c$ & 5.046 & 0.018 \\
$c$ does not Granger cause $y^{2}$ & 5.796 & 0.011 \\
$t$ does not Granger cause $c$ & 1.448 & 0.259 \\
$c$ does not Granger cause $t$ & 15.052 & 0.001 \\
$e d$ does not Granger cause $c$ & 4.236 & 0.030 \\
$c$ does not Granger cause $e d$ & 4.766 & 0.021 \\
$u$ does not Granger cause $c$ & 2.048 & 0.157 \\
$c$ does not Granger cause $u$ & 0.367 & 0.697 \\
\hline
\end{tabular}

sions, implying that the speed of environmental improvement is greater when an economy reaches a certain income threshold compared to the initial degradation speed. Education level has a positive effect on emissions, being significant only in the long run, suggesting that rising education level exposes the population to wider knowledge for the consumption of technology-intensive products and that possible environmental awareness, which depends on education level, does not takes place in Russia. On the other hand, the urbanization level in the Russian Federation has a strong negative impact on $\mathrm{CO}_{2}$ emissions, implying better organization for a clean environment in urban areas. Similar results have been found for India by Managi and Jena (2008), but with lower magnitude.

To examine the direction of the impact of series, the pairwise Granger causality test was conducted. The results of the causality test are presented in Table 6 , where the null hypothesis of the test is no causality. There is unidirectional cau- 
sality running from $\mathrm{CO}_{2}$ emissions to trade openness. The causality test did not reject the null hypothesis for relationships between carbon emissions and the urbanization level, suggesting that there is no relation between these two variables. The test provides evidence of a bi-directional Granger causality between carbon emissions and the remaining four variables, energy consumption, real income, real income squared and education.

The final stage of the ARDL approach is to estimate the stability of the model by employing the cumulative sum (CUSUM) and the cumulative sum of squares (CUSUMSQ) stability tests of Brown et al. (1975). Figs. 1, 2 and 3 illustrate the results of the tests. The test is applied to equations 4, 6 and 7 for Models 1, 2 and 3, respectively. The plots of the CUSUM statistics are located within 5 percent significance critical bounds for all three models; however, the plots of the CUSUMSQ statistics cross the critical value bounds for models 1 and 3 and are only slightly tangent to the critical value bound for model 2 .

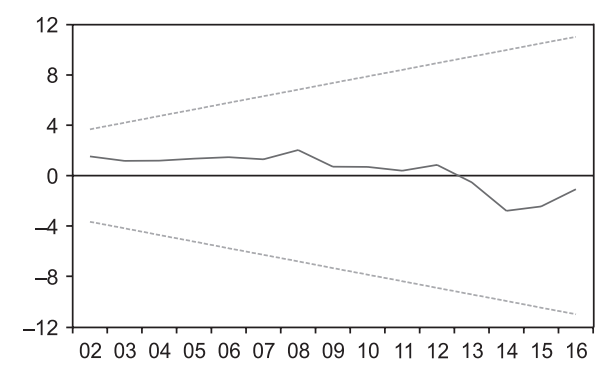

- CUSUM $\cdots$ Significance

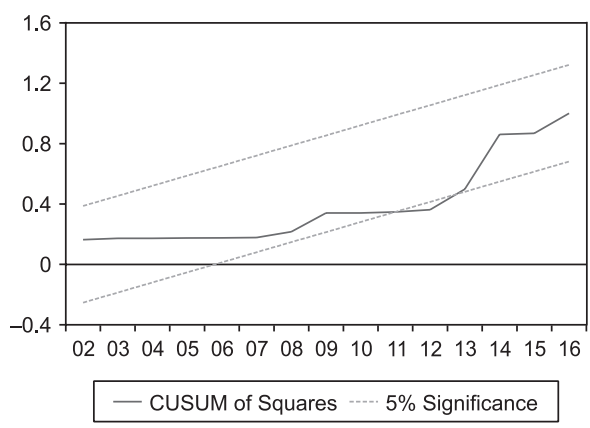

Fig. 1. Stability estimations for Model 1.
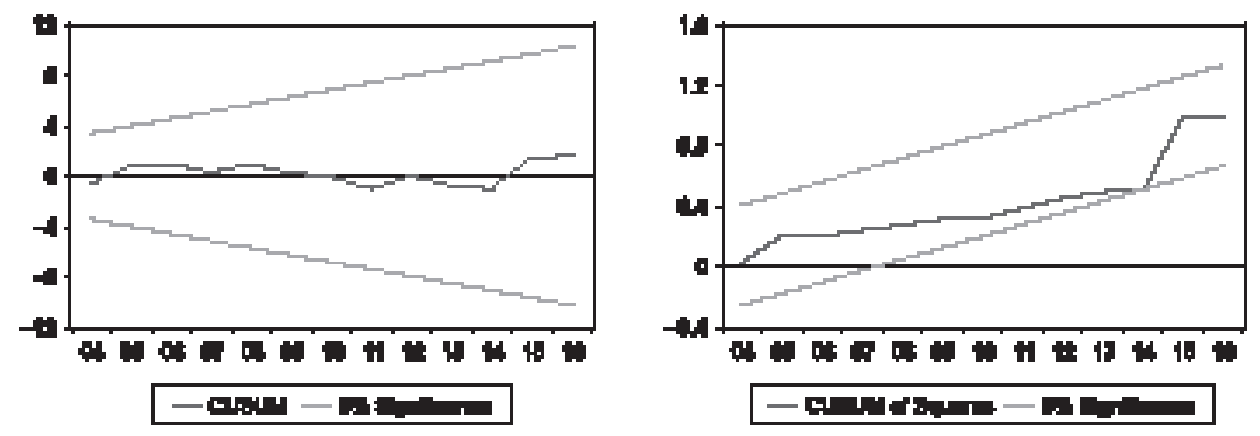

Fig. 2. Stability estimations for Model 2.
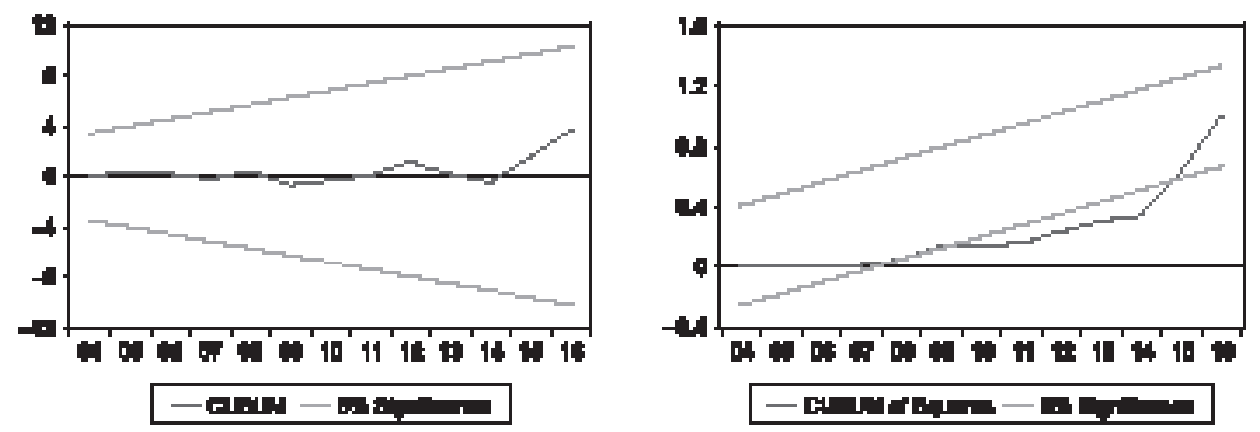

Fig. 3. Stability estimations for Model 3. 
Table 7

Chow forecast test.

\begin{tabular}{lcc}
\hline & F-statistics & Likelihood ratio \\
\hline Model 1 & $1.46(0.26)$ & $12.62(0.05)$ \\
Model 2 & $0.48(0.69)$ & $2.14(0.54)$ \\
Model 3 & $6.80(0.01)$ & $56.11(0.00)$ \\
\hline
\end{tabular}

Notes: Probabilities are reported in brackets. The null hypothesis of the Chow forecast test is no structural breaks.

As the results of the CUSUM and the CUSUMSQ test may not always produce similar figures, to check the robustness of the results, the Chow forecast test of Chow (1960) was employed (Leow, 2004; Islam et al., 2013, Arouri et al., 2014). The Chow forecast test examines parameters for structural breaks. The results of the test are presented in Table 7, where the null hypothesis of no structural change is tested for the period 2010-2012 for Model 1, for the period 2014-2016 for Model 2 and for the period 2007-2009 for Model 3. The periods are chosen on the basis of CUSUMSQ tests, where plots cross the 5 percent critical value line. In the case of Model 1, F-statistics failed to reject the null hypothesis of no structural breaks, while the LR statistics rejected the null hypothesis at a significance level of 5 percent. Therefore, the result for the first model is inconclusive, as the two statistics produce conflicting results. Both statistics failed to reject the null hypothesis for the second model, implying that Model 2 can be considered a reliable model for forecast and policy implications analysis. In the case of Model 3, both statistics rejected the null hypothesis, indicating that Model 3 is not an appropriate model for forecast and policy implications based on the results of the Granger causality tests.

\section{Conclusion}

The main aim of this study is to test the EKC hypothesis in the Russian Federation for the period 1991-2016. In order to avoid the possible problem of omitted variables in addition to trade, education and urbanization, variables are introduced to the model. Three models are estimated in this study. The first model employs energy use per capita, real income per capita, square of real income, trade and education as independent variables. The second model employs the variable of urbanization instead of education. Finally, the third model employs the variables of both education and urbanization in addition to main independent variables. In all three models, carbon dioxide emission per capita is employed as a dependent variable, a measure of environmental quality. The results provide enough evidence to conclude that the EKC hypothesis is valid for Russia, indicating an increase in carbon dioxide emissions with economic growth; however, after income reaches a certain threshold, $\mathrm{CO}_{2}$ declines. In all three models, the error correction term is significant with an expected negative sign implying that deviations from long-run equilibrium are adjusted by estimated variables in about one year for all models. The results of Granger's causality test demonstrate bidirectional Granger causality relationships between the pairs of $\mathrm{CO}_{2}$ and energy use, $\mathrm{CO}_{2}$ and real income, $\mathrm{CO}_{2}$ and the square of real income, and $\mathrm{CO}_{2}$ and education. A one-way causality runs through $\mathrm{CO}_{2}$ to trade and there is no causality between $\mathrm{CO}_{2}$ and urbanization. In order to measure the stability of model parameters, the CUSUM and CUSUMSQ techniques and the Chow forecast test were employed. The results provide evidence of parameter 
stability only for the second model, where the results of tests are inconclusive for the first model and reject the stability of parameters in the third model. Therefore, only the results of the second model may be employed for policy in Russia. From the results of the second model estimations, it can be concluded that economic growth has a short-run impact on $\mathrm{CO}_{2}$, energy use determines $\mathrm{CO}_{2}$ in both the short and long runs, while urbanization has significant high long-run impact on emissions.

Based on the results of the estimations, a number of policy implications can be derived for the Russian Federation. The results support the EKC hypothesis, which states that the relationships of $\mathrm{CO}_{2}$ emissions and economic growth have an inverted U-shape. Therefore, policy-makers should continue to implement policies to sustain economic development that leads to the use of cleaner technologies for lower carbon dioxide emissions. There is strong evidence that energy use has a destructive impact, while the level of urbanization has a refining effect on environmental quality. Therefore, policy-makers should focus on decreasing energy intensity, maintaining environmental policies in urban areas and implementing efficient environmental policies in rural areas to decrease the difference between urban and rural areas. Finally, education in Russia is found to have a damaging effect on environmental quality; therefore, new policies should be directed to increase environmental awareness among the population.

\section{References}

Acaravci, A., \& Özturk, I. (2010). On the relationship between energy consumption, CO2 emissions and economic growth in Europe. Energy, 35(12), 5412-5420. https://doi.org/10.1016/j. energy.2010.07.009

Agras, J., \& Chapman, D. (1999). A dynamic approach to the environmental Kuznets curve hypothesis. Ecological Economics, 28(2), 267-277. https://doi.org/10.1016/S0921-8009(98)00040-8

Al-Mulali, U., \& Özturk, I. (2016). The investigation of environmental Kuznets curve hypothesis in the advanced economies: The role of energy prices. Renewable \& Sustainable Energy Reviews, 54, 1622-1631. https://doi.org/10.1016/j.rser.2015.10.131

Al-Mulali, U., Saboori, B., \& Özturk, I. (2015). Investigating the environmental Kuznets cure hypothesis in Vietnam. Energy Policy, 76, 123-131. https://doi.org/10.1016/j.enpol.2014.11.019

Ang, J. B. (2007). $\mathrm{CO}_{2}$ emissions, energy consumption, and output in France. Energy Policy, 35(10), 4772-4778. https://doi.org/10.1016/j.enpol.2007.03.032

Arbulu, I., Lozano, J., \& Maquieira, J. R. (2015). Tourism and solid waste generation in Europe: A panel data assessment of the environmental Kuznets curve. Waste Management (New York, N.Y.), 46, 628-636. https://doi.org/10.1016/j.wasman.2015.04.014

Arouri, M., Shahbaz, M., Onchang, R., Islam, F., \& Teulon, F. (2014). Environmental Kuznets curve in Thailand: Cointegration and causality analysis (Working paper No. 204). Paris: IPAG Business School.

Arrow, K., Bolin, B., Costanza, R., Dagupta, P., Folke, C., Holling, C. S., . . Pimentel, D. (1996). Economic growth, carrying capacity, and the environment. Ecological Economics, 15(2), 9195. https://doi.org/10.1016/0921-8009(95)00059-3

Baek, J. (2015). Environmental Kuznets curve for $\mathrm{CO} 2$ emissions: The case of Arctic countries. Energy Economics, 50, 13-17. https://doi.org/10.1016/j.eneco.2015.04.010

Balaguer, J., \& Cantavella, M. (2018). The role of education in the environmental Kuznets curve. Evidence from Australian data. Energy Economics, 70, 289-296. https://doi.org/10.1016/j. eneco.2018.01.021

Brajer, V., Mead, R. W., \& Xiao, F. (2008). Health benefits of tunneling through the Chinese environmental Kuznets curve (EKC). Ecological Economics, 66(4), 674-686. https://doi. org/10.1016/j.ecolecon.2007.11.002 
Brown, R. L., Durbin, J., \& Evans, J. M. (1975). Techniques for testing the constancy of regression relations over time. Journal of the Royal Statistical Society. Series B. Methodological, 37, 149-163.

Bultei, E. H., \& Soest, D. P. (2001). Environmental degradation in developing countries: Households and the (reverse) environmental Kuznets curve. Journal of Development Economics, 65(1), 225-235. https://doi.org/10.1016/S0304-3878(01)00135-3

Chang, M.-C. (2015). Room for improvement in low carbon economies of G7 and BRICS countries based on the analysis of energy efficiency and environmental Kuznets curves. Journal of Cleaner Production, 99, 140-151. https://doi.org/10.1016/j.jclepro.2015.03.002

Chow, G. (1960). Test of equality between sets of coefficients in two linear regressions. Econometrica, 28(3), 591-605. https://doi.org/10.2307/1910133

Cole, M.A.(2004). Trade, the pollution haven hypothesis and the environmental Kuznets curve: Examining the linkages. Ecological Economics, 48(1), 71-81. https://doi.org/10.1016/j.ecolecon.2003.09.007

Dickey, D. A., \& Fuller, W. A. (1979). Distribution of the estimators for autoregressive time series with a unit root. Journal of the American Statistical Association, 74(366a), 427-431.

Ekins, P. (1997). The Kuznets curve for the environmental and economic growth: Examining the evidence. Environment and Planning A. Economy and Space, 29(5), 805-830. https://doi. org/10.1068/a290805

Elliot, G., Rothenberg, T., \& Stock, J. (1996). Efficient tests for an autoregressive unit root. Econometrica, 64(4), 813-836. https://doi.org/10.2307/2171846

Estive, V., \& Tamarit, C. (2012). Threshold cointegration and nonlinear adjustment between CO2 and income: The environmental Kuznets curve in Spain, 1857-2007. Energy Economics, 34(6), 2148-2156. https://doi.org/10.1016/j.eneco.2012.03.001

Farhani, S., Mrizak, S., Chaibi, A., \& Rault, C. (2014). The environmental Kuznets curve and sustainability: A panel data analysis. Energy Policy, 71, 189-198. https://doi.org/10.1016/j. enpol.2014.04.030

Fodha, M., \& Zaghdoud, O. (2010). Economic growth and pollutant emissions in Tunisia: An empirical analysis of the environmental Kuznets curve. Energy Policy, 38(2), 1150-1156. https://doi.org/10.1016/j.enpol.2009.11.002

Gangadharan, L., \& Valenzuela, M. R. (2001). Interrelationships between income, health and the environment: Extending the environmental Kuznets curve hypothesis. Ecological Economics, 36(3), 513-531. https://doi.org/10.1016/S0921-8009(00)00250-0

Grossman, G. M., \& Krueger, A. B. (1995). Economic growth and the environment. The Quarterly Journal of Economics, 112(2), 353-378. https://doi.org/10.2307/2118443

Haliciogly, F. (2009). An econometric study ofCO2 emissions, energy consumption, income and foreign trade in Turkey. Energy Policy, 37(3), 1156-1164. https://doi.org/10.1016/j.enpol.2008.11.012

Halicioglu, F., \& Ketenci, N. (2016). The impact of international trade on environmental quality: The case of transition countries. Energy, 109, 1130-1138. https://doi.org/10.1016/j. energy.2016.05.013

He, J. (2016). Is the environmental Kuznets curve hypothesis valid for developing countries? A survey. GREDI Working paper, No. 07-03.

He, J., \& Richard, P. (2010). Environmental Kuznets curve for $\mathrm{CO}_{2}$ in Canada. Ecological Economics, 69(5), 1083-1093. https://doi.org/10.1016/j.ecolecon.2009.11.030

Heerink, N., Mulatu, A., \& Bulte, E. (2001). Income inequality and the environment: Aggregation bias in environmental Kuznets Curves. Ecological Economics, 38(3), 359-367. https://doi. org/10.1016/S0921-8009(01)00171-9

Hill, R. J., \& Magnani, E. (2002). An exploration of the conceptual and empirical basis of the environmental Kuznets curve. Australian Economic Papers, 41(2), 239-254. https://doi. org/10.1111/1467-8454.00162

Hossain, M. S. (2011). Panel estimation for CO2 emissions, energy consumption, economic growth, trade openness and urbanization of newly industrialized countries. Energy Policy, 39(11), 6991-6999. https://doi.org/10.1016/j.enpol.2011.07.042

Islam, F., Shabaz, M., Ahmed, A. U., \& Alam, M. M. (2013). Financial development and energy consumption nexus in Malaysia: A multivariate time series analysis. Economic Modelling, 30, 435-441. https://doi.org/10.1016/j.econmod.2012.09.033

Ivanova, V. I., \& Vertkina, D. (2017). Environmental Kuznets curve: Russian cities' case. In Y. G. Yasin (Ed.), XVII International science conference on economic and social development problems (pp. 156-165). Moscow: National Research University Higher School of Economics. 
Iwata, H., Okada, K., \& Samreth, S. (2010). Empirical study on the environmental Kuznets curve for CO2 in France: The role of nuclear energy. Energy Policy, 38(8), 4057-4063. https://doi. org/10.1016/j.enpol.2010.03.031

Jalil, A., \& Feridun, M. (2011). The impact of growth, energy and financial development on the environment in China: A cointegration analysis. Energy Economics, 33(2), 284-291. https://doi.org/10.1016/j.eneco.2010.10.003

Jayanthakumaran, K., \& Liu, Y. (2012). Openness and the environmental Kuznets curve: Evidence from China? Economic Modelling, 29(3), 566-576. https://doi.org/10.1016/j. econmod.2011.12.011

Jebli, M. B., \& Youssef, S. B. (2015). The environmental Kuznets curve, economic growth renewable and non-renewable energy, and trade in Tunisia. Renewable \& Sustainable Energy Reviews, 47, 173-185. https://doi.org/10.1016/j.rser.2015.02.049

Jebli, M. B., Youssef, S. B., \& Özturk, I. (2016). Testing environmental Kuznets curve hypothesis: The role of renewable and non-renewable energy consumption and trade in OECD countries. Ecological Indicators, 60, 824-831. https://doi.org/10.1016/j.ecolind.2015.08.031

Kasman, A., \& Duman, Y. S. (2015). CO2 emissions, economic growth, energy consumption, trade and urbanization in new EU member and candidate countries: A panel data analysis. Economic Modelling, 44, 97-103. https://doi.org/10.1016/j.econmod.2014.10.022

Katircioğlu, S. T. (2014). Testing the tourism-induced EKC hypothesis: The case of Singapore. Economic Modelling, 41, 383-391. https://doi.org/10.1016/j.econmod.2014.05.028

Katircioğlu, S. (2017). Investigating the role of oil prices in the conventional EKC model: Evidence from Turkey. Asian Economic and Financial Review, 7(5), 498-508. https://doi.org/10.18488/ journal.aefr/2017.7.5/102.5.498.508

Katircioğlu, S. T., \& Taspinar, N. (2017). Testing the moderating role of financial development in an environmental Kuznets curve: Empirical evidence from Turkey. Renewable \& Sustainable Energy Reviews, 68(1), 572-586. https://doi.org/10.1016/j.rser.2016.09.127

Khan, S. A. R., Zaman, K., \& Zhang, Y. (2016). The relationship between energy-resource depletion, climate change, health resources and the environmental Kuznets curve: Evidence from the panel of selected developed countries. Renewable \& Sustainable Energy Reviews, 62, 468-477. https://doi.org/10.1016/j.rser.2016.04.061

Korppoo, A., \& Kokorin, A. (2017). Russia's 2020 GHG emissions target: Emission trends and implementation. Climate Policy, 17(2), 113-130. https://doi.org/10.1080/14693062.2015.10 75373

Lau, L. S., Choong, C. K., \& Eng, Y. K. (2014). Investigation of the environmental Kuznets curve for carbon emissions in Malaysia: Do foreign direct investment and trade matter? Energy Policy, 68, 490-497. https://doi.org/10.1016/j.enpol.2014.01.002

Leow, Y. G. (2004). A reexamination of the exports in Malaysia's economic growth: After Asian financial crisis, 1970-2000. International Journal of Management Sciences, 11, 179-204.

Li, T., Wang, Y., \& Zhao, D. (2016). Environmental Kuznets curve in China: New evidence from dynamic panel analysis. Energy Policy, 91, 138-147. https://doi.org/10.1016/j. enpol.2016.01.002

Lindmark, M. (2002). An EKC-pattern in historical perspective: Carbon dioxide emissions, technology, fuel prices and growth in Sweden 1870-1997. Ecological Economics, 42(1-2), 333-347. https://doi.org/10.1016/S0921-8009(02)00108-8

Magnani, E. (2000). The environmental Kuznets curve, environmental protection policy and income distribution. Ecological Economics, 32(3), 431-443. https://doi.org/10.1016/S09218009(99)00115-9

Managi, S., \& Jena, P. R. (2008). Environmental productivity and Kuznets curve in India. Ecological Economics, 65(2), 432-440. https://doi.org/10.1016/j.ecolecon.2007.07.011

Mihalischev, S., \& Raskina, Y. (2015). Environmental Kuznets curve: The case of Russia (Working Paper No. Ec-03/15). European University at St. Petesburg, Department of Economics.

Millimet, D. L., List, J. A., \& Stengos, T. (2006). The environmental Kuznets curve: Real progress or misspecified models? The Review of Economics and Statistics, 85(4), 1038-1047. https:// doi.org/10.1162/003465303772815916

Narayan, P. K., \& Narayan, S. (2010). Carbon dioxide emissions and economic growth: Panel data evidence from developing countries. Energy Policy, 38(1), 661-666. https://doi.org/10.1016/j. enpol.2009.09.005 
Özturk, I., \& Al-Mulali, U. (2015). Investigating the validity of the environmental Kuznets curve hypothesis in Cambodia. Ecological Indicators, 57, 324-330. https://doi.org/10.1016/j. ecolind.2015.05.018

Pablo-Romero, M. P., \& Jesus, J. D. (2016). Economic growth and energy consumption: The EnergyEnvironmental Kuznets curve for Latin America and the Caribbean. Renewable \& Sustainable Energy Reviews, 60, 1343-1350. https://doi.org/10.1016/j.rser.2016.03.029

Pablo-Romero, M. P., Cruz, L., \& Barata, E. (2017). Testing the transport energy-environmental Kuznets curve hypothesis in the EU27 countries. Energy Economics, 62, 257-269. https://doi. org/10.1016/j.eneco.2017.01.003

Panayotou, T. (1993). Empirical tests and policy analysis of environmental degradation at different stages of economic development (Working Paper No. WP238). Geneva: International Labor Office, Technology and Employment Programme.

Pao, H. T., \& Tsai, C. M. (2011). Multivariate Granger causality between CO2 emissions, energy consumption, FDI (foreign direct investment) and GDP (gross domestic product): Evidence from a panel of BRIC (Brazil, Russian Federation, India, and China) countries. Energy, 36(1), 685-693. https://doi.org/10.1016/j.energy.2010.09.041

Pao, H. T., Yu, H. C., \& Yang, Y. H. (2011). Modeling the CO2 emissions, energy use, and economic growth in Russia. Energy, 36(8), 5094-5100. https://doi.org/10.1016/j.energy.2011.06.004

Pesaran, M., \& Pesaran, B. (1997). Working with Microfit 4.0: Interactive economic analysis. Oxford: Oxford University Press.

Pesaran, M. H., \& Shin, Y. (1999). An autoregressive distributed lag modelling approach to cointegration analysis. In S. Storm (Ed.), Econometrics and economic theory in $20^{\text {th }}$ century: The Ragnar Frisch centennial symposium (pp. 371-413). Cambridge: Cambridge University Press.

Pesaran, M. H., Shin, Y., \& Smith, R. J. (2001). Bounds testing approaches to the analysis of level relationships. Journal of Applied Econometrics, 16(3), 289-326. https://doi.org/10.1002/jae.616

Phillips, P. C., \& Perron, P. (1988). Testing for a unit root in time series regression. Biometrika, 75(2), 335-346. https://doi.org/10.1093/biomet/75.2.335

Richmond, A. K., \& Kaufmann, R. K. (2006). Energy prices and turning points: The relationship between income and energy use/carbon emissions. Energy Journal, 27(4), 157-180. https://doi. org/10.5547/ISSN0195-6574-EJ-Vol27-No4-7

Rudenko, D., \& Skripnuk, D. (2016). Environmental Kuznets curve: The case of Arctic Russian regions. SGEM2016 Conference Proceedings, 5 (3), 209-216.

Saboori, B., Sulaiman, J. B., \& Mohd, S. (2012). An empirical analysis of the environmental Kuznets curve for $\mathrm{CO} 2$ emissions in Indonesia: The role of energy consumption and foreign trade. International Journal of Economics and Finance, 4(2), 243-251. https://doi.org/10.5539/ijef.v4n2p243

Saboori, B., \& Sulaiman, J. (2013). Environmental degradation, economic growth and energy consumption: Evidence of the environmental Kuznets curve in Malaysia. Energy Policy, 60, 892-905. https://doi.org/10.1016/j.enpol.2013.05.099

Sayed, A. R. M. A., \& Sek, S. K. (2013). Environmental Kuznets curve: Evidences from developed and developing economies. Applied Mathematical Sciences, 7(22), 1081-1092. https://doi. org/10.12988/ams.2013.13098

Shahbaz, M., Mutascu, M., \& Azim, P. (2013). Environmental Kuznets curve in Romania and the role of energy consumption. Renewable \& Sustainable Energy Reviews, 18, 165-173. https://doi.org/10.1016/j.rser.2012.10.012

Shahbaz, M., Dube, S., Özturk, I., \& Jalil, A. (2015). Testing the environmental Kuznets curve hypothesis in Portugal. International Journal of Energy Economics and Policy, 5(2), 475-481.

Sirag, A., Matemilola, B. T., Law, S. H., \& Bany-Ariffin, A. N. (2017). Does environmental Kuznets curve hypothesis exist? Evidence from dynamic panel threshold. Journal of Environmental Economics and Policy, 7(2), 145-165. https://doi.org/10.1080/21606544.2017.1382395

Stern, D. I. (2004). The rise and fall of the environmental Kuznets curve. World Development, 32(8), 1419-1439. https://doi.org/10.1016/j.worlddev.2004.03.004

Suri, V., \& Chapman, D. (1998). Economic growth, trade and energy: Implications for the environmental Kuznets curve. Ecological Economics, 25(2), 195-208. https://doi.org/10.1016/S09218009(97)00180-8

Tamazian, A., Chousa, J. P., \& Vadlamannati, K. C. (2009). Does higher economic and financial development lead to environmental degradation: Evidence from BRIC countries. Energy Policy, 37(1), 246-253. https://doi.org/10.1016/j.enpol.2008.08.025 
Torras, M., \& Boyce, J. K. (1998). Income, inequality and pollution: A reassessment of the environmental Kuznets curve. Ecological Economics, 25(2), 147-160. https://doi. org/10.1016/S0921-8009(97)00177-8

Wang, J., Da, L., Song, K., \& Li, B. L. (2008). Temporal variations of surface water quality in urban, suburban and rural areas during rapid urbanization in Shanghai, China. Environmental Pollution, 152(2), 387-393. https://doi.org/10.1016/j.envpol.2007.06.050

Yang, X., Lou, F., Sun, M., Wang, M., \& Wang, Y. (2017). Study of the relationship between greenhouse gas emissions and the economic growth of Russia based on the environmental Kuznets curve. Applied Energy, 193, 162-173. https://doi.org/10.1016/j.apenergy.2017.02.034

Zaman, K., Shahbaz, M., Loganathan, N., \& Raza, S. A. (2016). Tourism development, energy consumption and environmental Kuznets curve: Trivariate analysis in the panel of developed and developing countries. Tourism Management, 54, 275-283. https://doi.org/10.1016/j. tourman.2015.12.001

\section{Appendix}

The ARDL framework for Models 2 and 3, respectively is expressed as follows:

$$
\begin{aligned}
\Delta c_{t}=\gamma_{0} & +\sum_{i=1}^{p} \gamma_{1 i} \Delta c_{t-i}+\sum_{i=0}^{p} \gamma_{2 i} \Delta e_{t-i}+\sum_{i=0}^{p} \gamma_{3 i} \Delta y_{t-i}+\sum_{i=0}^{p} \gamma_{4 i} \Delta y_{t-i}^{2}+ \\
& +\sum_{i=0}^{p} \gamma_{5 i} \Delta t r_{t-i}+\sum_{i=0}^{p} \gamma_{6 i} \Delta u_{t-i}+\gamma_{7} c_{t-i}+\gamma_{8} e_{t-1}+\gamma_{9} y_{t-1}+ \\
& +\gamma_{10} y_{t-1}^{2}+\gamma_{11} t r_{t-1}+\gamma_{12} u_{t-1}+\epsilon_{t} \\
\Delta c_{t}=\theta_{0} & +\sum_{i=1}^{p} \theta_{1 i} \Delta c_{t-i}+\sum_{i=0}^{p} \theta_{2 i} \Delta e_{t-i}+\sum_{i=0}^{p} \theta_{3 i} \Delta y_{t-i}+\sum_{i=0}^{p} \theta_{4 i} \Delta y_{t-i}^{2}+ \\
& +\sum_{i=0}^{p} \theta_{5 i} \Delta t r_{t-i}+\sum_{i=0}^{p} \theta_{6 i} \Delta e d_{t-i}+\theta_{7} u_{t-i}+\theta_{8} c_{t-1}+\theta_{9} e_{t-1}+ \\
& +\theta_{10} y_{t-1}^{2}+\theta_{11} \Delta y_{t-1}^{2}+\theta_{12} t r_{t-1}+\theta_{13} e d_{t-1}+\theta_{12} u_{t-1}+\omega_{t}
\end{aligned}
$$

The ECM for Models 2 and 3, respectively is expressed as follows:

$$
\begin{aligned}
\Delta c_{t}=\tau_{0} & +\sum_{i=1}^{p} \tau_{1 i} \Delta c_{t-i}+\sum_{i=0}^{p} \tau_{2 i} \Delta e_{t-i}+\sum_{i=0}^{p} \tau_{3 i} \Delta y_{t-i}+\sum_{i=0}^{p} \tau_{4 i} \Delta y_{t-i}^{2}+ \\
& +\sum_{i=0}^{p} \tau_{5 i} \Delta t r_{t-i}+\sum_{i=0}^{p} \tau_{6 i} \Delta u_{t-i}+\lambda_{2} E C_{t-i}+\psi_{t} \\
\Delta c_{t}=\sigma_{0} & +\sum_{i=1}^{p} \sigma_{1 i} \Delta c_{t-i}+\sum_{i=0}^{p} \sigma_{2 i} \Delta e_{t-i}+\sum_{i=0}^{p} \sigma_{3 i} \Delta y_{t-i}+\sum_{i=0}^{p} \sigma_{4 i} \Delta y_{t-i}^{2}+ \\
& +\sum_{i=0}^{p} \sigma_{5 i} \Delta t r_{t-i}+\sum_{i=0}^{p} \sigma_{6 i} \Delta e d_{t-i}+\sum_{i=0}^{p} \sigma_{7 i} \Delta u_{t-i}+\lambda_{3} E C_{t-i}+\chi_{t}
\end{aligned}
$$

